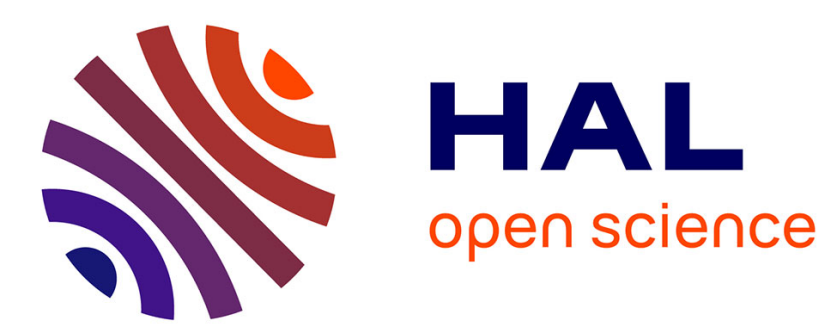

\title{
Design of a Truncated Cardiotoxin-I Analogue with Potent Insulinotropic Activity
}

Thi Tuyet Nhung Nguyen, Benjamin Folch, Myriam Letourneau, Nam Hai Truong, Nicolas Doucet, Alain Fournier, David Chatenet

\section{- To cite this version:}

Thi Tuyet Nhung Nguyen, Benjamin Folch, Myriam Letourneau, Nam Hai Truong, Nicolas Doucet, et al.. Design of a Truncated Cardiotoxin-I Analogue with Potent Insulinotropic Activity. Journal of Medicinal Chemistry, 2014, 57 (6), pp.2623-33. 10.1021/jm401904q · hal-01177382

\section{HAL Id: hal-01177382 \\ https://hal.science/hal-01177382}

Submitted on 14 Sep 2015

HAL is a multi-disciplinary open access archive for the deposit and dissemination of scientific research documents, whether they are published or not. The documents may come from teaching and research institutions in France or abroad, or from public or private research centers.
L'archive ouverte pluridisciplinaire HAL, est destinée au dépôt et à la diffusion de documents scientifiques de niveau recherche, publiés ou non, émanant des établissements d'enseignement et de recherche français ou étrangers, des laboratoires publics ou privés. 


\section{Design of a Truncated Cardiotoxin-I Analogue with Potent Insulinotropic Activity}

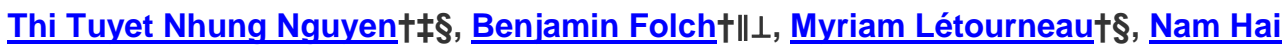

Truongł, Nicolas Doucet $\dagger \| \perp$, Alain Fournier ${ }^{*} \dagger \S$, and David Chatenet ${ }^{*} \dagger \S$

† INRS-Institut Armand-Frappier, Université du Québec, 531 Boulevard des Prairies Ville de Laval, Québec H7 V 1B7, QuébecCanada

‡ Vietnam Academy of Science and Technology, Institute of Biotechnology, 18 Hoang Quoc Viet, Caugiay, Hanoi, Vietnam

$\S$ Laboratoire International Associé Samuel de Champlain, INSERM-INRS-Université de Rouen, Mont-Saint-Aignan Cedex, 76821, Rouen, France

" PROTEO, the Quebec Network for Research on Protein Function, Structure, and Engineering, Université Laval, 1045 Avenue de la Médecine, Québec G1 V 0A6, Québec, Canada

${ }^{\perp}$ GRASP, the Groupe de Recherche Axé sur la Structure des Protéines, McGill University, 3649 Promenade Sir William Osler, Montréal H3G 0B1, Québec, Canada

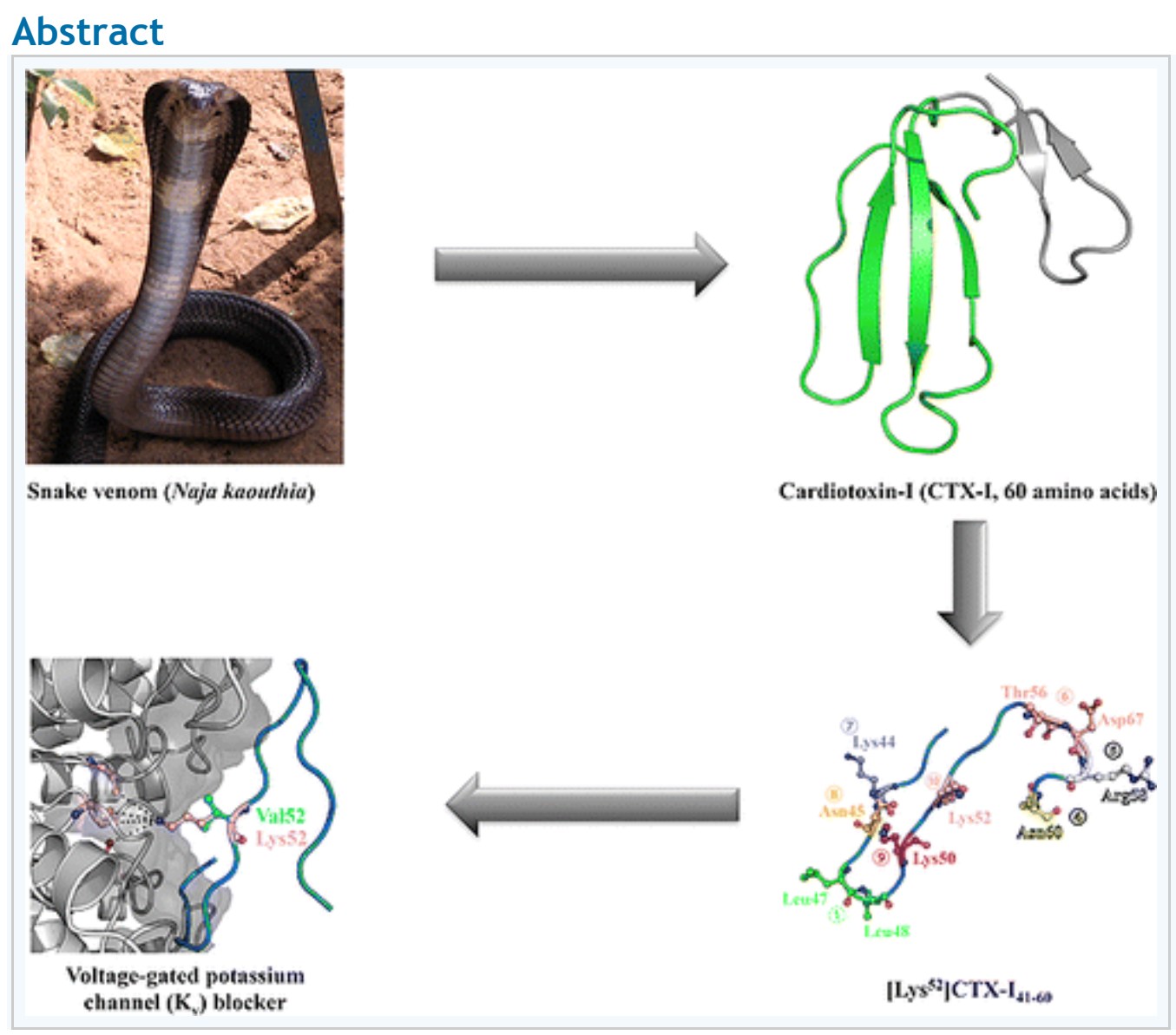


Insulin secretion by pancreatic $\beta$-cells in response to glucose or other secretagogues is tightly coupled to membrane potential. Various studies have highlighted the prospect of enhancing insulin secretion in a glucose-dependent manner by blocking voltage-gated potassium channels $\left(\mathrm{K}_{\mathrm{v}}\right)$ and calcium-activated potassium channels $\left(\mathrm{K}_{\mathrm{Ca}}\right)$. Such strategy is expected to present a lower risk for hypoglycemic events compared to $\mathrm{K}_{\mathrm{ATP}}$ channel blockers. Our group recently reported the discovery of a new insulinotropic agent, cardiotoxin-I (CTX-I), from theNaja kaouthia snake venom. In the present study, we report the design and synthesis of $\left[\mathrm{Lys}^{52}\right] \mathrm{CTX}-\mathrm{I}_{41-60}$ via structure-guided modification, a truncated, equipotent analogue of CTX-I, and demonstrate, using various pharmacological inhibitors, that this derivative probably exerts its action through $\mathrm{K}_{\mathrm{v}}$ channels. This new analogue could represent a useful pharmacological tool to study $\beta$-cell physiology or even open a new therapeutic avenue for the treatment of type 2 diabetes.

\section{Introduction}

From a pathophysiological standpoint, type 2 diabetes, accounting for almost $90 \%$ of diabetic patients, is a progressive disease causing abnormal carbohydrate, lipid, and protein metabolism associated with insulin resistance and impaired insulin secretion.(1) Insulin resistance is involved in disease progression and is considered a major component of diabetes-associated complications such as blindness, heart diseases, kidney problems, nerve damage, and erectile dysfunction. $(2,3)$ Despite current therapies, a significant number of patients with type 2 diabetes are unable to reach the glycemic target.(4) Therefore, glucose-lowering and disease-modifying drugs, working through unconventional targets, are still required for the treatment of type 2 diabetes.

After protein kinases and $\mathrm{G}$ protein-coupled receptors, voltage-gated ion channels represent the largest group of signaling structures encoded by the human genome. Glucose-stimulated insulin secretion from pancreatic $\beta$-cells is regulated by a series of electrogenic events leading to insulin exocytosis.(5) In $\beta$-cells, the release of insulin can be associated to the activation of 3 types of potassium channels: ATP-sensitive potassium channel ( $\left.K_{\text {ATP }}\right)$, calcium-activated potassium channels $\left(\mathrm{K}_{\mathrm{ca}}\right)$, and voltage-gated potassium $\left(\mathrm{K}_{\mathrm{v}}\right)$ channels.(6) For decades, modulators of $\mathrm{K}_{\text {ATP }}$ channels have been used as oral treatment for type 2 diabetes. However, increasing evidence has demonstrated that modulation of $\mathrm{K}_{\mathrm{v}}$ channels, including $\mathrm{K}_{\mathrm{v} 1.3}, \mathrm{~K}_{\mathrm{v} 1.4}, \mathrm{~K}_{\mathrm{v} 2.1}$, and $\mathrm{K}_{\mathrm{ca}}$ channels like $\mathrm{K}_{\text {ca3.1. }}$, could represent attractive 
targets for the management of type 2 diabetes. One major physiological function of these channels is the maintenance of a negative membrane potential, which facilitates sustained $\mathrm{Ca}^{2+}$ signaling during $\beta$-cell activation by providing the electrical driving force for $\mathrm{Ca}^{2+}$ entry through voltage-independent $\mathrm{Ca}^{2+}$ channels.(7) Inhibition of those channels will therefore prolong action potentials, sustain the opening of voltage-dependent $\mathrm{Ca}^{2+}$ channels, and enhance glucose-induced insulin release.(8) $\mathrm{K}_{\mathrm{v}}$ and $\mathrm{K}_{\mathrm{c} a}$ channels have attracted much attention as potential therapeutic targets for the treatment of type 2 diabetes. $(8,9)$

Animal venoms have been broadly recognized as a great source of biologically active molecules.(10) Each year, several natural toxins with highly specific actions are discovered, characterized, and used both as pharmacological tools and as templates for drug design.(11, 12) The evolved biodiversity of these compounds can act on a wide variety of membrane bound proteins, enzymes, and ion channels.(13-15) Widely distributed in living organisms, potassium channels, involved in the control and regulation of various cell functions, are therefore regarded as key targets for the treatment of various diseases.(16) Over the years, venoms from spiders, scorpions, snakes, bees, and marine animals have yielded polypeptide inhibitors of mammalian $\mathrm{K}^{+}$channels such as charybdotoxin $(\mathrm{CHT})$, margatoxin, and maurotoxin.(17) Because of their small size, compact and rigid structure, high potency, and selectivity, toxins have emerged as highly valuable tools for research and drug development for numerous indications, including diabetes.

Recently, we have isolated, from the venom of the Vietnamese snake Naja kaouthia, a peptide that potently stimulated insulin secretion in pancreatic $\beta$-cells, i.e., INS-1E.(18) Its characterization showed that it was a 60 -amino acid peptide known as cardiotoxin-I (CTX-I). Structural homology with known insulinotropic peptide toxins suggested that $\left[\mathrm{Lys}^{52}\right] \mathrm{CTX}-\mathrm{I}_{41-}$ ${ }_{60}$ could act as a potassium channel blocker. In the present study, we have rationally designed an equipotent and shorter version of CTX-I using molecular modeling and demonstrated that the mechanism underlying its insulinotropic activity is clearly related to the inhibition of potassium channels.

Results and Discussion

\section{Molecular Modeling}


Numerous potassium channel modulators have been engineered using natural peptides isolated from scorpion, snake, and sea anemone venoms as chemical templates.(17) Most polypeptide toxins bind with high affinity to a cavity at the entrance of $\mathrm{K}^{+}$channel pores,(17) which are formed by the juxtaposition of 4 protein units identified as $A, B, C$, and D. These toxins, generally characterized by three well-conserved disulfide bridges, mediate the interaction with the channel pore using a conserved three-residue motif that plays a crucial role in establishing the toxin-blocking mechanism.(17) This motif is comprised of conserved amino acids or similar property side chains pointing toward the interior of the pore. The toxin motif properties are defined as follows: (1) a strictly conserved lysine at the center of the toxin interface, (2) an asparagine or polar residue at one end of the toxin, and (3) an arginine or positively charged residue at the opposite end (Figures $1 \mathrm{~A}$ and $2 \mathrm{~A}$ ). This conserved motif is not always obvious and can sometimes be difficult to observe structurally, much like in BgK (PDB entry 1BGK) and ShK (PDB entry 1ROO), two toxins that were shown to interact with potassium channels in a similar fashion (Figure 1B).(19, 20) Nevertheless, both BgK and ShK preserve the central lysine $\left(\operatorname{Lys}^{22}\right.$ and Lys ${ }^{25}$ ) and the positive interaction ( $\operatorname{Arg}^{11}$ and Lys ${ }^{7}$ ) to successfully achieve pore blocking, in addition to the partial conservation of the polar interface $\left(\mathrm{Met}^{21}\right.$ and $\left.\mathrm{Gl}{ }^{24}\right)$. Several attempts at performing automated superpositions between BgK/ShK and $\mathrm{CHT}$ remained inconclusive due to the low structural similarity between these two low-homology toxins. To demonstrate the structural motif conservation and the similar binding interface, we performed manual superpositions of BgK and ShK with CHT, a $\mathrm{K}_{\mathrm{v} 1.3}$ and $\mathrm{K}_{\mathrm{Ca} 3.1}$ blocker (Figure 2C,D). Our results demonstrate that the charged/hydrophobic surface repartition is critical for the optimal interaction with various $\mathrm{K}^{+}$channels. While potassium channel blocking is achieved through a conserved consensus sequence, binding specificity is achieved by subtle differences in amino acid composition.

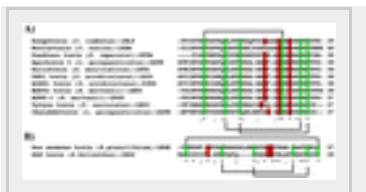

Figure 1. Sequence alignment of $K_{v 1.3}$ potassium channel blocker toxins from various organisms. $(A, B)$ The six conserved cysteine residues are highlighted in green and their corresponding disulfide bonds are depicted as black lines. The highly conserved residue motif playing a crucial role in pore-blocking activity is depicted in red.(22, 51-56) Sequence alignment was performed with ClustalW2.(41) 


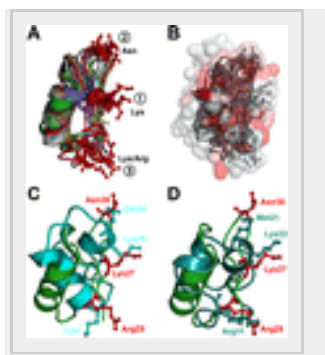

Figure 2. $\mathrm{K}_{\mathrm{v} 1.3}$ channel blocker features essential for the binding with $\mathrm{Kv}$ channels. (A) Structural superposition of common $\mathrm{K}_{\mathrm{v} 1.3}$ channel blockers displaying the conserved three-residue motif playing a critical role in establishing the toxin-penetrating interaction (PDB

entries $1 \mathrm{HLY}, 1 \mathrm{SXM}, 2 \mathrm{PTA}, 2 \mathrm{~A} 9 \mathrm{H}, 1 \mathrm{KTX}, 1 \mathrm{SCO}, 2 \mathrm{CK} 4,1 \mathrm{BKT}, 2 \mathrm{~K} 4 \mathrm{U}, 1 \mathrm{HP} 2$, and 2A9H). (B) Structural superposition of $\mathrm{K}_{\mathrm{v} 1.3}$ blockers displaying the importance of the charged/hydrophobic surface repartition of $\mathrm{K}_{\mathrm{v} 1.3}$ blockers (same PDB entries, with the addition of $1 \mathrm{ROO}$ and 1BGK). (C,D) Superposition of CHT (PDB entry $2 \mathrm{A9H}$, chain $\mathrm{E}$ ) with the divergent $\mathrm{K}_{\mathrm{v} 1.3}$ blockers sea anemone toxin ((C) PDB entry 1 RBGK) and ShK toxin ((D) PDB entry 1 ROO).

We recently reported that cardiotoxin-I (CTX-I), isolated from the Naja kaouthia snake venom, can modulate insulin secretion from INS-1E cells without affecting cell viability and integrity.(18)A sequence and structure alignment between this 60 -amino acid containing three-finger toxin and other $\mathrm{K}^{+}$channel blockers did not reveal any similarity (Figure 1A). As depicted for the ShK and BgK toxins, which are quite distinct in sequence and structure, our in silico analysis showed that one face of CTX-I preserves the mandatory structural motif that favors an interaction with $\mathrm{K}^{+}$channels.(18) This assumption was further investigated by comparing the putative CTX-I-interacting structure with that of the $\mathrm{K}_{\mathrm{v} 1.3} / \mathrm{K}_{\mathrm{ca3.1}}$ channel blocker $\mathrm{CHT}$. Homology models of $\mathrm{K}_{\mathrm{ca3} .1}$ and $\mathrm{K}_{\mathrm{v} 1.3}$, based on the crystal structure of the KcsA channel, have previously illustrated the similar pore-blocking interaction mode of $\mathrm{K}_{\mathrm{v}} / \mathrm{K}_{\mathrm{Ca}}$ channel blockers.(21) Our structural investigation of CHT with the KcsA channel (PDB entry 2A9H) also revealed specific contacts associated with the extracellular surface of the ion channel.(22) Extensive analysis of the above-mentioned complex revealed that 10 residues play important roles in the $\mathrm{CHT} / \mathrm{KcsA}$ binding interface by establishing hydrophobic contacts $(\mathrm{HC})$, hydrogen bonding interactions $(\mathrm{HB})$, electrostatic interactions (EI), and salt bridges (SB) with the $\mathrm{K}^{+}$channel (Table 1, Figure 3A-C). The CHT residues $\mathrm{Phe}^{2}, \operatorname{Trp}^{14}, \mathrm{Ser}^{37}$, and Tyr $^{36}$ make hydrophobic contacts with $\mathrm{K}^{+}$channel residues Val ${ }^{84}$ (unit D), Tyr ${ }^{82}$ (unit D), $\mathrm{Ala}^{58}$ (unit D), Leu ${ }^{81}$ (unit D), and Val ${ }^{84}$ (unit C), respectively (depicted in green, cyan, magenta,and orange, respectively, in Figure $3 \mathrm{~A}-\mathrm{C})$. A hydrogen bond is formed between $\mathrm{CHT}-\mathrm{Met}^{29}$ and $\mathrm{Tyr}^{82}$ of the $\mathrm{K}^{+}$channel (unit A), which also interfaces with $\mathrm{CHT}-\mathrm{Arg}^{34}$ through 
a cation- $\pi$ interaction (depicted in yellow in Figure $3 \mathrm{~A}-\mathrm{C}$ ). The side chain of $\mathrm{CHT}-$

$\mathrm{Asn}^{30}$ forms hydrogen bonding and electrostatic interactions with the $\mathrm{Asp}^{64}$ side chain and the backbone atoms of $\mathrm{Leu}^{81}$, two residues found in unit $\mathrm{A}$ of the $\mathrm{K}^{+}$channel (depicted in peach color in Figure $3 \mathrm{~A}-\mathrm{C}$ ). We also observed electrostatic interactions between CHT-Lys ${ }^{38}$ and the backbone atoms of Gly ${ }^{56}$ (unit A) and $A^{2} a^{57}$ (unit A) (depicted in white in Figure 3A-C). Salt bridges are also involved at the interface between $\mathrm{CHT}$ and the $\mathrm{K}^{+}$channel. Salt bridges link CHT-Lys ${ }^{11}$ and CHT-Arg ${ }^{25}$ to $\mathrm{Asp}^{64}$ (unit B) and $\mathrm{Asp}^{64}$ (unit C) of the $\mathrm{K}^{+}$channel, respectively (depicted in blue and magenta in Figure 3A-C). In addition, CHT-Arg(25) makes an electrostatic contact with backbone atoms of $\mathrm{Leu}^{81}$ in the $\mathrm{K}^{+}$channel (unit C). Finally, one of the most important residues of this binding interaction, CHT-Lys ${ }^{27}$, is deeply buried within the $\mathrm{K}^{+}$pore. It establishes four electrostatic interactions with the four backbone oxygen atoms of the $\mathrm{Tyr}^{78}$ residue present in each protein unit of the channel $(A, B, C$ and $D$, depicted in pink in Figure 3A-C,E).

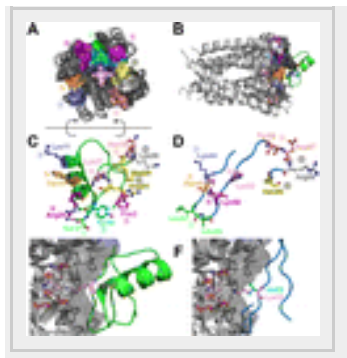

Figure 3. Binding surface similarities between charybdotoxin (CHT) and $\mathrm{CTX}-\mathrm{I}_{41-60}$ complexed to $\mathrm{K}_{\mathrm{v}}$ channels. (A) Surface representation of the $\mathrm{K}_{\mathrm{v}}$ channel displaying the 10 binding regions interacting with $\mathrm{CHT}$. The color code surface in $(\mathrm{A})$ depicts channel pore regions that bind to the same colorcoded residues in $\mathrm{CHT}\left(180^{\circ}\right.$ rotation of $(\mathrm{C})$ about the $x$-axis). (B) The $\mathrm{K}_{\mathrm{v}}$ channel blocked by CHT (side view). (C) Atomic representation of the $10 \mathrm{CHT}$ residues that mediate important interactions with $\mathrm{Kv}$ channels. Binding surface interactions between $\mathrm{Kv}$ and $\mathrm{CHT}$ are depicted using the same color code as in (A). (D) Atomic representation of $C T X-I_{41-60}$ residues that mediate binding with $\mathrm{K}_{\mathrm{v}}$ channels. The $C T X-I_{41-60}$ peptide preserves the same structural properties as $\mathrm{CHT}$ (same color code as $(C)$ ). (E) Zoomed view of CHT-Lys ${ }^{27}$ interacting with the $\mathrm{K}_{\mathrm{v}}$ channel pore backbone of residues $\mathrm{Tyr}^{78}$ from A, B, $\mathrm{C}$, and D chains. (F) To better mimic the toxin-penetrating mode, $\mathrm{Val}^{52}$ was changed to a lysine (Lys ${ }^{52}$ ) to generate peptide $\left[\right.$ Lys $\left.^{52}\right] \mathrm{CTX}-\mathrm{I}_{41-60}$.

\section{Table 1. Charybdotoxin and CTX-I Residues Interacting with $\mathrm{K}_{\mathrm{v}}$ Channel}

$$
\text { charybdotoxin }^{\text {interaction }^{\mathrm{a}}} \quad \mathbf{K}_{\mathrm{v}} \text { channel (chain ID)interaction }^{\mathrm{a}} \quad \text { CTX-I }
$$




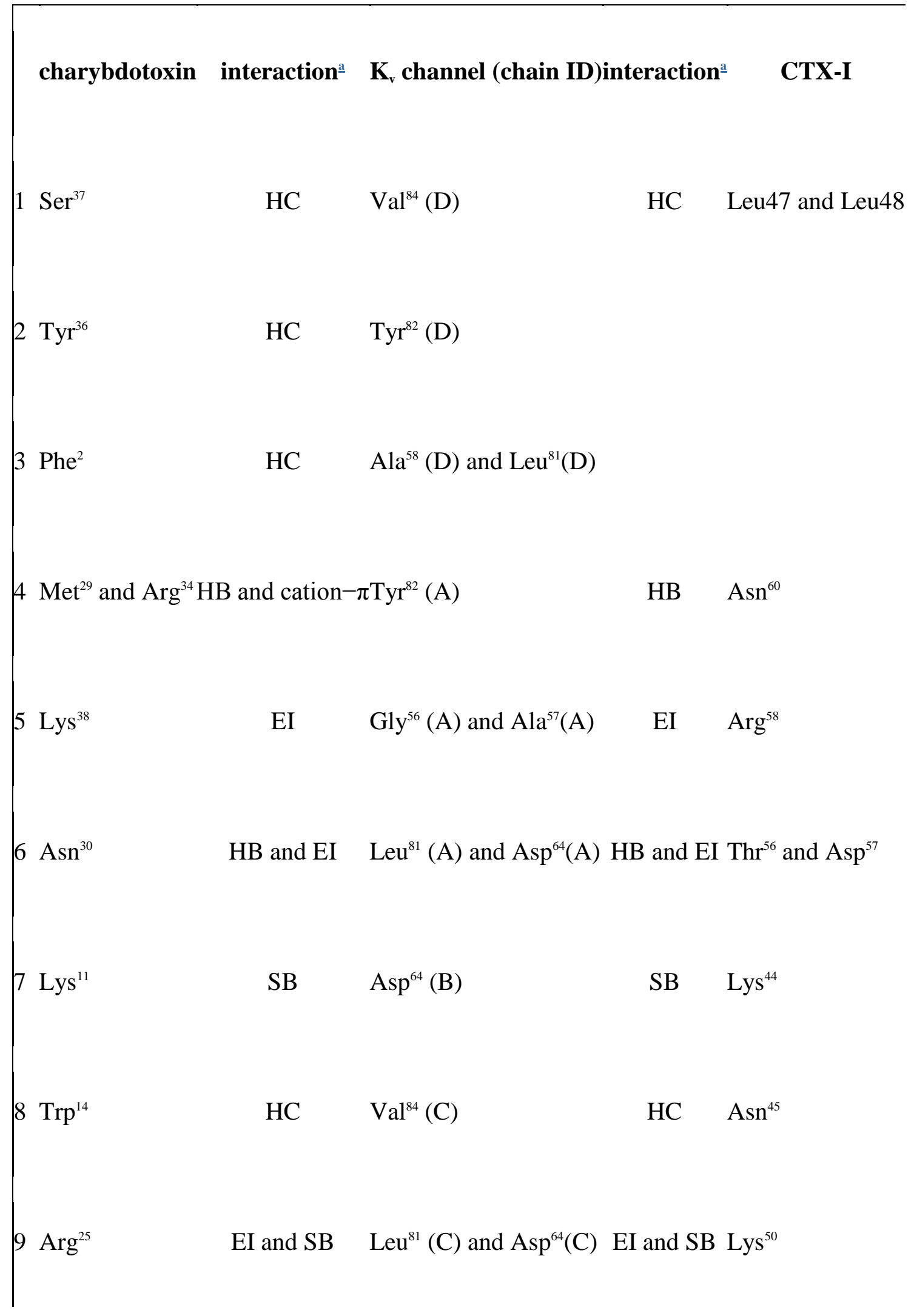




\title{
charybdotoxin interaction ${ }^{\underline{a}} \quad \mathbf{K}_{v}$ channel (chain ID)interaction ${ }^{\underline{a}} \quad$ CTX-I
}

\author{
10Lys ${ }^{27} \quad$ EI $\quad \operatorname{Tyr}^{78}(\mathrm{~A}, \mathrm{~B}, \mathrm{C}, \mathrm{D}) \quad$ EI $\quad \operatorname{Lys}^{50}\left(L^{2} \mathrm{~s}^{52}\right)^{\underline{\mathrm{b}}}$
}

a

$\mathrm{HC}=$ Hydrophobic contact, $\mathrm{HB}=$ Hydrogen bond, cation $-\pi=$ cation $-\pi$ interaction, $\mathrm{El}=$ electrostatic interaction, SB = salt bridge.

b

The substitution of Val ${ }^{52}$ with Lys better mimics the CHT-Lys ${ }^{27}$ side chain than CTX-I-Lys ${ }^{50}$.

When comparing the CTX-I three-residue motif with the above-mentioned $\mathrm{CHT}$ interface, at least 8 of the 10 surface interactions are conserved, suggesting the presence of a similar binding interface with $\mathrm{K}_{\mathrm{v}}$ and $\mathrm{K}_{\mathrm{Ca}}$ channels (Table 1 and Figure 3C,D). As presented in Table 1, most of the surface interactions described for CHT are preserved when CTX-I binds to a $\mathrm{K}^{+}$channel. Hydrophobic contacts established by $\mathrm{CHT}-\mathrm{Ser}^{37}$ and $\mathrm{CHT}-\mathrm{Trp}^{14}$ are mimicked by CTX-I-Leu ${ }^{47}$ and CTX-I-Leu ${ }^{48}$, whereas hydrogen bonds produced by CHT-Met ${ }^{29}$ and CHT$\mathrm{Asn}^{30}$ are mirrored by the CTX-I-Asn ${ }^{60}$ and CTX-I-Thr ${ }^{56}$ side chains. In addition, salt bridges observed in the $\mathrm{CHT} / \mathrm{K}^{+}$channel complex, involving $\mathrm{CHT}-\mathrm{Lys}^{11}$ and $\mathrm{CHT}-\mathrm{Arg}^{25}$, are reproduced by CTX-I-Lys ${ }^{44}$ and CTX-I-Lys ${ }^{50}$. Similarly, the electrostatic interactions formed by CHT residues $\mathrm{Arg}^{25}, \mathrm{Lys}^{27}, \mathrm{Met}^{29}, \mathrm{Asn}^{30}$, and Lys ${ }^{38}$ are replicated within CTX-I by the Lys ${ }^{50}$, $\mathrm{Asp}^{57}$, and $\mathrm{Arg}^{58}$ side chains. Initial experiments aimed at validating our in silico assumption have thus been focused on the design, synthesis, and pharmacological characterization of a shorter version of CTX-I encompassing the putative $\mathrm{K}_{\mathrm{v}} / \mathrm{K}_{\mathrm{Ca}}$ interacting interface, i.e., $\mathrm{CTX}-\mathrm{I}_{41-}$ 60. Analysis of the putative CTX-I interaction model suggests that CTX-I-Lys ${ }^{23}$ is probably minimally involved in a $\mathrm{K}^{+}$channel interaction because its side chain is deeply buried and inaccessible within CTX-I. However, $\mathrm{Val}^{52}$ is ideally positioned and has an excellent solvent accessibility. Therefore, we hypothesize that a valine to lysine replacement at position 52 could mimic the structural and functional properties of the central lysine side chain found in $\mathrm{K}^{+}$channel blockers (Figure 3F). To confirm this hypothesis, the synthetic analogue $\left[\right.$ Lys $\left.^{52}\right]$ CTX- ${ }_{41-60}$ in which the native Val ${ }^{52}$ residue is replaced with a Lys moiety is evaluated. 


\section{Cytotoxic Activity of CTX-I and Related Analogues}

Most cardiotoxins (CTXs) are known to exert cytotoxic activities through the necrotic and apoptotic pathways by binding to zwitterionic phospholipids through hydrophobic interactions $(23,24)$ and to anionic glycosaminoglycans via electrostatic interactions.(25) By interfacing with the lipid bilayer, the first two loops of CTXs, generally characterized by a high content of hydrophobic residues, induce a rearrangement of the plasma membrane that damages the cell.(26) The propensity of the N-terminal region of CTX-I, CTX-I ${ }_{1-39}$, as well as its C-terminal fragments, CTX-I $\mathrm{I}_{41-60}$ and [Lys $\left.{ }^{52}\right] \mathrm{CTX}-\mathrm{I}_{41-60}$ (Figure 4A), to induce INS-1E cell death has been evaluated by the MTT and LDH assays. Interestingly, CTX-I was practically devoid of cytotoxicity, whereas fragment 1-39, encompassing the first two loops, significantly affected INS-1E cell survival and integrity (Figure 4B,C) at a concentration of $10^{-6} \mathrm{M}$. Conversely, their full length counterpart, $\mathrm{CTX}-\mathrm{I}_{41-60}$ and its related analogue [Lys $\left.{ }^{52}\right] \mathrm{CTX}-\mathrm{I}_{41-}$ ${ }_{60}$ did not exert any significant cytotoxic activity on INS-1E cells (Figure 4B,C).

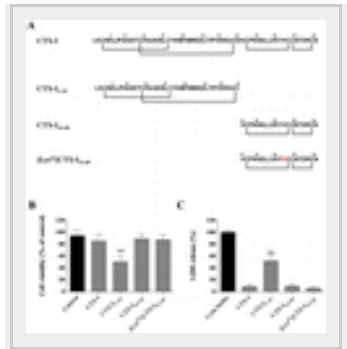

Figure 4. Sequence and cytotoxic action of CTX-I and related analogues. (A) Amino acid sequence and disulfide bridge connectivity of native Naja kaouthiaCTX-I and its related derivatives. (B,C) Cytotoxic activities of CTX-I and its related derivatives on INS-1E cells. Statistical comparisons were performed by ANOVA followed by a Dunnett's multiple comparison test, and differences were considered significant when ${ }^{*} P<0.05,{ }^{* *} P<0.01$, and ${ }^{* * *} P<0.001$.

\section{Insulinotropic Action of CTX-I and Related Analogues}

Our understanding of the mechanisms behind insulin secretion remains somewhat elusive. Nonetheless, certain features of this process have been clearly and repeatedly demonstrated.(27) Briefly, extracellular glucose is transported into the $\beta$-cell by a glucose transporter. Elevation of intracellular glucose concentration triggers membrane depolarization and provokes an influx of extracellular calcium.(27) The resulting increase in intracellular calcium is considered as the primary signal for exocytosis of insulin-containing secretory granules. 
Initial experiment revealed that CTX-I and its shorter unmodified fragment, i.e., $C T X-\mathrm{I}_{41-60}$, increased the intracellular $\mathrm{Ca}^{2+}$ mobilization with a similar potency $\left(\mathrm{pEC}_{50}=8.85 \pm 0.17\right.$ versus $8.67 \pm 0.15$, respectively) (Figure $5 \mathrm{~A}$ ). However, as depicted in Figure $5 \mathrm{~A}, \mathrm{~B}, \mathrm{CTX}-\mathrm{I}_{41-}$ ${ }_{60}$ was significantly less efficient compared to its full-length counterpart. Interestingly, and in accordance with our in silico predictive model, introduction of a Lys residue at position 52, i.e., $\left[\mathrm{Lys}^{52}\right] \mathrm{CTX}-\mathrm{I}_{41-60}$, completely restored the $\mathrm{Ca}^{2+}$ release activity (Figure 5A,B). This shorter derivative was further evaluated for its ability to induce insulin release in the absence and the presence of glucose. Without glucose, $\left[\mathrm{Lys}^{52}\right] \mathrm{CTX}-\mathrm{I}_{41-60}$ still significantly triggered insulin exocytosis similar to CTX-I (Figure 5C). Indeed, the concentration of insulin reached after the treatment with $\left[\mathrm{Lys}^{52}\right] \mathrm{CTX}-\mathrm{I}_{41-60}$ in the absence of glucose was similar to that of in the presence of $20 \mathrm{mM}$ glucose (Figure $5 \mathrm{C}$ ). Much like its full length counterpart, [Lys ${ }^{52} \mathrm{CTX}_{\mathrm{C}} \mathrm{I}_{41-}$ ${ }_{60}$ worked synergistically in the presence of glucose as demonstrated by the enhanced insulinotropic effect (Figure 5C). Finally, like CTX-I and other insulinotropic polypeptide toxins such as guangxitoxin-1 or mastoparan,(18) this short derivative stimulated insulin secretion from INS-1E cells in the presence of glucose in a concentration-dependent fashion (Figure 5D). Altogether, this 20-mer derivative, shorter than most insulinotropic polypeptide toxins, was able to trigger insulin exocytosis in the absence or the presence of glucose by increasing INS-1E intracellular $\mathrm{Ca}^{2+}$ concentration.

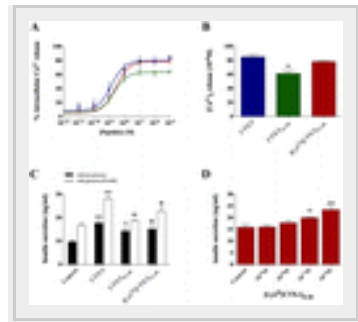

Figure 5. CTX-I- and [Lys $\left.{ }^{52}\right]$ CTX-I $\mathrm{I}_{41-60}$ biological activities. (A) Effect of CTX-I and its related derivatives on intracellular calcium mobilization in INS-1E cells. (B) Maximal effect induced by CTX-I $\left(10^{-6} \mathrm{M}\right)$ and its related derivatives $\left(10^{-6} \mathrm{M}\right)$ on intracellular calcium mobilization in INS-1E cells $(C)$ Insulinotropic activity of CTX-I and its related derivatives $\left(10^{-6} \mathrm{M}\right)$ in the presence or absence of glucose. (D) Concentration-dependent insulinotropic activity of $\left[\mathrm{Lys}^{52}\right] \mathrm{CTX}-\mathrm{I}_{41-60}$ in the presence of glucose. Statistical comparisons were performed by ANOVA followed by a Dunnett's multiple comparison test, and differences were considered significant when ${ }^{*} P<0.05$, ${ }^{* *} P<0.01,{ }^{* * *} P<0.001,{ }^{\circledR} P<0.05$, ${ }^{\text {\&\& }} P<$ $0.01,{ }^{\circledR} P<0.05$, and ${ }^{\S s} P<0.01$.

Putative Cell Signaling Involved in CTX-I- and [Lys $\left.{ }^{52}\right] C T X-I_{41-60}-$ Induced Insulin Release 
As previously reported, CTX-I is unable to bind to GLP-1 receptors present in INS-1E cells.(18)Such receptors are currently the target of various incretin derivatives including Liraglutide, a long acting GLP-1 agonist, and Exenatide, the synthetic version of exendin-4, a hormone isolated from the saliva of the Gila monster.(28) Despite its inability to displace ${ }^{125 \mid-}$ GLP-1 from INS-1E cells, CTX-I and its truncated derivative could still activate GLP-1 receptor through allosteric modulation.(29) Indeed, by binding to a site that is different from the one occupied by the orthosteric ligand GLP-1, these derivatives could select a specific subset of receptor conformation, thereby inducing the activation of second messengers, such as cyclic adenosine monphosphate (cAMP) and protein kinase $A(P K A)$, both associated with GLP-1-mediated insulin release.(30) Treatment of INS-1E cells in the presence of $20 \mathrm{mM}$ glucose and 2',5'-dideoxy-adenosine (a cell permeable adenylyl cyclase inhibitor) or H89 (a protein kinase $A$ inhibitor) did not affect the insulinotropic activity of CTX-I and [Lys $\left.{ }^{52}\right] \mathrm{CTX}-\mathrm{I}_{41-}$ ${ }_{60}$ (Figure 6A,B). Therefore, we conclude that these peptides do not exert their action through GLP-1 receptor activation.

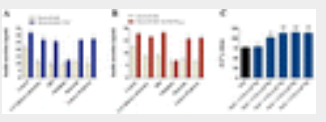

Figure 6. Mechanism involved in CTX-I- and $\left[\mathrm{Lys}^{52}\right] \mathrm{CTX}-\mathrm{I}_{41-60}$-induced insulin release. $(A, B)$ Effect of various pharmacological inhibitors on CTX-I- and $\left[\mathrm{Lys}^{52}\right] \mathrm{CTX}-\mathrm{I}_{41-60}$-induced insulin release. (C) Effect of increasing concentrations of CTX-I on NGF-induced intracellular calcium mobilization. Statistical comparisons were performed by One-Way ANOVA, and differences were considered significant when ${ }^{*} P<0.05,{ }^{* *} P<0.01$, and ${ }^{* \star *} P<0.001$.

Elevation of intracellular $\mathrm{Ca}^{2+}$ level is actually regarded as the essential component for secretagogue-induced insulin release.(30) As depicted earlier, CTX-I and [Lys $\left.{ }^{52}\right]$ CTX-I ${ }_{41-}$ ${ }_{60}$ both enhance intracellular $\mathrm{Ca}^{2+}$ concentration in INS-1E cells, thus leading to insulin exocytosis (Figure 5A-D). Interestingly, nifedipine, a dihydropyridine $\mathrm{Ca}^{2+}$ channel blocker that primarily blocks L-type $\mathrm{Ca}^{2+}$ channels, completely abolished CTX-I- and [Lys $\left.{ }^{52}\right] \mathrm{CTX}-\mathrm{I}_{41-60^{-}}$ mediated insulin release (Figure 6A,B). It has been reported that nerve growth factor (NGF) actions, and more particularly $\mathrm{Ca}^{2+}$ influx, can be mediated by NGF receptors linked to nifedipine-sensitive L-type calcium channels.(31) The concomitant treatment of INS-1E cells with NGF $(50 \mathrm{ng} / \mathrm{mL})$ and $\left[\mathrm{Lys}^{52}\right] \mathrm{CTX}-\mathrm{I}_{41-60}\left(10^{-9} \mathrm{M}\right)$ had no effect on $\mathrm{Ca}^{2+}$ release (Figure $\left.6 \mathrm{C}\right)$. However, an increase of $\left[\mathrm{Lys}^{52}\right] \mathrm{CTX}-\mathrm{I}_{41-60}$ concentration (ranging from $10^{-8} \mathrm{M}$ to $10^{-5} \mathrm{M}$ ) caused a significant change in intracellular $\mathrm{Ca}^{2+}$ mobilization (Figure 6C). Generally, when 
the plasma membrane is depolarized, voltage-sensitive $\mathrm{Ca}^{2+}$ channels open to allow $\mathrm{Ca}^{2+}$ entry into the cell.(27) The resulting rise in cytosolic $\mathrm{Ca}^{2+}$, apart from triggering insulin release, also activates several $\mathrm{K}^{+}$channels, thereby leading to membrane repolarization and closure of the $\mathrm{Ca}^{2+}$ channels.(6) As such, inhibition of these currents broadens the duration of action potentials that maintain the plasma membrane in a depolarized state and sustain the calcium influx through opened calcium channels. $(8,9)$ On the basis of the results obtained with NGF and nifedipine, $\left[\mathrm{Lys}^{52}\right] \mathrm{CTX}-\mathrm{I}_{41-60} \mathrm{Could}$ potentialize $\mathrm{Ca}^{2+}$ entry and therefore insulin release by acting on those channels.

The $\mathrm{K}_{\text {ATP }}$ channel is another essential mediator for glucose-dependent insulin release from the pancreatic $\beta$-cells. Closure of these channels, as a result of increased glucose metabolism, leads to the release of insulin. Various compounds, targeting the sulfonylurea receptor subunit forming $\mathrm{K}_{\text {ATP }}$ channels, have been used primarily for the treatment of type 2 diabetes mellitus.(32) The ability of both CTX-I and its shorter modified derivative to stimulate insulin secretion in the absence of glucose suggests that $\mathrm{K}_{\mathrm{ATP}}$ is not involved in their biological activity. In accordance, despite the treatment of INS-1E cells with diazoxide (a $\mathrm{K}_{\text {ATP }}$ channel opener) or 2-deoxy-D-glucose (an ATP depletor), both CTX-I and [Lys $\left.{ }^{52}\right]$ CTX-I $\mathrm{I}_{41-}$ ${ }_{60}$ fully exert their insulinotropic activity demonstrating the noninvolvement of these channels.

Like CHT, CTX-I and its derivative could exert their effect through the closure of $\mathrm{K}_{\mathrm{v}}$ and/or $\mathrm{K}_{\mathrm{Ca}}$ channels. $(8,9) \mathrm{K}_{\mathrm{Ca}}$ channels in $\beta$-cells consist of at least two different components, a large conductance $\mathrm{K}_{\mathrm{Ca}}$ channel with no clear-cut physiological function(33) and a small $\mathrm{K}_{\mathrm{Ca}}$ current.(34) The latest current is linked to the depolarization-induced rhythmic electrical activity of $\beta$-cells, which is important for insulin secretion.(35) Despite extensive research, selective channel blockers are still limited and most polypeptide toxins acting on those channels are rather nonselective.(36) Inhibiting the big potassium (BK) channels using pharmacological inhibitors provoke an increase in the myogenic tone of various arteries.(37) In our studies, CTX-I and $\left[\mathrm{Lys}^{52}\right] \mathrm{CTX}-\mathrm{I}_{41-60}$ were both unable to induce any contraction of rat aortic ring even when treated at a concentration of $10^{-5} \mathrm{M}$. It is therefore unlikely that BK channels are involved in $\left[\mathrm{Lys}^{52}\right] \mathrm{CTX}-\mathrm{I}_{41-60}$-mediated insulin release.

Next, we examined the ability of $\left[\mathrm{Lys}^{52}\right] \mathrm{CTX}-\mathrm{I}_{41-60}$ to modulate $\mathrm{K}^{+}$efflux using a rubidium tracer to follow potassium movement across the cell membrane. INS-1E cells, initially incubated with ${ }^{86} \mathrm{RbCl}$, were exposed to physiological, low external potassium (low-K) conditions. A time-dependent efflux of ${ }^{86} \mathrm{Rb}^{+}$from the cells was observed. In the presence of high external 
potassium, the ${ }^{86} \mathrm{Rb}^{+}$efflux took place much more rapidly than in basal condition, reflecting the activity of $\mathrm{K}^{+}$channels in INS-1E cells (Figure $7 \mathrm{~A}$ ). ${ }^{86} \mathrm{Rb}^{+}$efflux from INS-1E cells was significantly inhibited by [ Lys $\left.^{52}\right] \mathrm{CTX}-\mathrm{I}_{41-60}$ in a concentration-dependent manner (Figure 7B). However, in comparison to AM-90216, a specific blocker of the time-dependent delayedrectifier $\mathrm{K}^{+}$current, this inhibition is weaker. Such difference could be explained by a lower binding affinity and as consequence a lower potency of [Lys $\left.{ }^{52}\right] \mathrm{CTX}-\mathrm{I}_{41-60}$ or could be the result of a $\left[\mathrm{Lys}^{52}\right] \mathrm{CTX}-\mathrm{I}_{41-60}$ subtype-selective action. It is well-known that TRAM-34, a $\mathrm{K}_{\text {ca3.1 }}$ specific blocker, is unable to depolarize wild-type $\beta$-cells under resting conditions.(38) The ability of our derivative to stimulate insulin secretion, probably through the depolarization of the membrane in resting condition, suggests that this analogue is probably not acting through $\mathrm{K}_{\mathrm{Ca}}$ channels but rather blocks $\mathrm{K}_{\mathrm{v}}$ channels. Such channels either produce, a fast transient current, $I_{A}$, or a slow inactivating, delayed rectifying current, $I_{D R} \cdot(39,40)$ Both currents exist in $\beta$-cells, with $I_{D R}$ being the major contributor to the repolarization of these cells. Blockage of $I_{D R}$ should enhance $\mathrm{Ca}^{2+i n f l u x}$ and lead to an increase in insulin secretion, as previously reported.(9) Specificity of our newly discovered compound will be further investigated through electrophysiology studies. However, it is likely that this newly designed polypeptide toxin is acting through $\mathrm{K}_{\mathrm{v}}$ channels to induce insulin secretion in INS-1E cells.

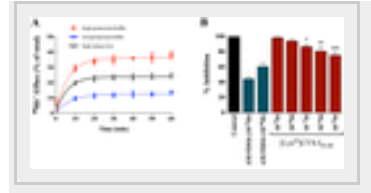

Figure 7. ${ }^{86} \mathrm{Rb}^{+}$efflux from INS-1E cells. (A) Time course of ${ }^{86} \mathrm{Rb}^{+}$efflux from INS-1E cells in low- $\mathrm{K}^{+}$and high- $\mathrm{K}^{+}$conditions. The $\mathrm{K}^{+}$component of ${ }^{86} \mathrm{Rb} \mathrm{b}^{+}$efflux, defined as the difference between high- and low$\mathrm{K}$, is indicated $(\mathbf{A})$. (B) Inhibition of ${ }^{86} \mathrm{Rb}^{+}$efflux from INS-1E cells by increasing concentrations of $\left[\right.$ Lys $\left.^{52}\right]$ CTX- $\left.\right|_{41-60}$. Statistical comparisons were performed by One- Way ANOVA, and differences were considered significant when ${ }^{*} P<0.05,{ }^{* *} P<0.01$, and ${ }^{* * *} P<0.001$.

\section{Conclusion}

Further investigations are still needed to confirm the physiological target of CTX-I and its related analogue $\left[\right.$ Lys $\left.^{52}\right] \mathrm{CTX}-\mathrm{I}_{41-60}$. The discovery of a reduced-size peptide triggering insulin release through a purported interaction with $\mathrm{K}_{\mathrm{v}}$ channels at the cell membrane could represent a new tool to improve our understanding of insulin release, and our knowledge regarding specific interaction related to $\mathrm{K}_{\mathrm{v}}$ blockage and specificity. Finally, this compound 
might be a key step in the development of a new therapeutic strategy for the treatment of type 2 diabetes.

\section{Experimental Section}

\section{Materials}

All Fmoc-protected amino acids and benzotriazol-1-yl-oxy-tris(dimethylamino)-phosphonium hexafluorophosphate (BOP) were obtained from Matrix Innovation Inc. (Montreal, QC, Canada), while Wang and Rink amide AM resins were from Chem-Impex International (Wood Dale, IL, USA). Diisopropylethylamine (DIPEA), diazoxide, nifedipine, nerve growth factor (NGF), 2-deoxy-D-glucose, and H89 were purchased from Sigma-Aldrich (Mississauga, ON, Canada). Trifluoroacetic acid (TFA) was obtained from PSIG (Montreal, QC, Canada). Acetonitrile (ACN), methanol (MeOH), dichloromethane (DCM), and $N, N$ dimethylformamide (DMF) were bought from Fisher Scientific (Nepean, ON, Canada). 2',5'Dideoxyadenosine and ${ }^{86} \mathrm{RbCl}$ were purchased from Calbiochem (Mississauga, ON, Canada) and PerkinElmer (Waltham, MA, USA), respectively. The calcium sensor Fura-2-AM was obtained from Life Technologies (Burlington, ON, Canada).

\section{Molecular Modeling}

Sequence alignments of various toxins presented in Figure 1 were performed with the ClustalW software.(41) All peptide structures automated and manual three-dimensional alignments were performed with PyMOL.(42) The hydrophobic surface representation displayed in Figure 2B was based on the hydrophobicity scale, as defined by Eisenberg et al.(43) Surfaces of the $\mathrm{K}_{\mathrm{v}}$ channel depicted in Figure 3 were generated with HOLLOW.(44) The virtual mutation introduced in the truncated CTX-I was performed with SCRWL4.(45) We used the RosettaDock server(46)and AutoDock(47) servers to perform docking simulations of a virtually truncated and substituted CTX-I peptide in presence of the Kv channel structure (PDB entry $2 \mathrm{~A} 9 \mathrm{H})$.

\section{Peptide Synthesis}

Syntheses of the CTX-I derivatives with C-terminal acid, CTX-I $\mathrm{I}_{41-60}$ and $\left[\mathrm{Lys}^{52}\right] \mathrm{CTX}-\mathrm{I}_{41-60}$, as well as the $\mathrm{CTX}-\mathrm{I}_{1-39}$ fragment with $\mathrm{C}$-terminal amide, were achieved following Fmoc chemistry protocols employing Fmoc-Asn(Trt)-Wang-resin and Rink-amide resin, respectively. Couplings, monitored with the qualitative ninhydrin test, were performed, in 
most cases, with a 3 equiv excess of the protected amino acids, based on the original substitution of the resins were mediated with BOP (3 equiv) and DIPEA (4.5 equiv) in DMF for $1 \mathrm{~h}$. Fmoc removal was achieved with 20\% piperidine in DMF for $20 \mathrm{~min}$. All peptides were cleaved from the resin support with simultaneous side chain deprotection by treatment with TFA containing 1,2-ethanedithiol (2.5\%), water (2.5\%), and triisopropylsilane (2.5\%) for $3 \mathrm{~h}$ at room temperature. The diethyl ether-precipitated crude peptides were purified by preparative reversed-phase HPLC using a Gemini $C_{18}$ column $(250 \mathrm{~mm} \times 21.2 \mathrm{~mm} ; 5 \mu \mathrm{m}$, $110 \AA$; Phenomenex, Torrance, CA, USA) and a linear gradient of acetonitrile in water containing $0.1 \%$ TFA. Purity and molecular mass of collected fractions were confirmed by analytical RP-HPLC and MALDI-TOF mass spectrometry. For each peptides, i.e., $\left[\right.$ Cys $\left.(\mathrm{Acm})^{3,21}, \mathrm{Cys}(\mathrm{tBu})^{14,38}\right] \mathrm{CTX}-\mathrm{I}_{1-39}$, $\left[\mathrm{Cys}(\mathrm{Acm})^{42,53}, \mathrm{Cys}(\mathrm{tBu})^{54,59}\right] \mathrm{CTX}-\mathrm{I}_{41-60}$, and $\left[\mathrm{Cys}(\mathrm{Acm})^{42,53}\right.$, Cys $\left.(\mathrm{tBu})^{54,59}, \mathrm{Lys}^{52}\right] \mathrm{CTX}-\mathrm{I}_{41-60}$, pure fractions (>95\%) containing the desired product were pooled and lyophilized. These peptides, characterized by two disulfide bridges, were further subjected to regioselective cysteine oxidation. Pure peptides were first dissolved $(1 \mathrm{mg} / \mathrm{mL})$ in $80 \%$ acetic acid and cyclized by the addition of iodine (10\% solution in methanol) until appearance of a stable orange color.(48) Thirty minutes later, ascorbic acid was added to quench the excess of iodine and the reaction mixture was then lyophilized. Following the formation of the first disulfide bridge, the Cys $(\mathrm{tBu})$-protected monodisulfide peptides were dissolved in TFA:DMSO:anisole (97.9:2:0.1) at a peptide concentration of $0.5 \mathrm{mg} / \mathrm{mL}$ and then mixed at RT for 40 min as previously described.(49) The cyclized products were finally precipitated by addition of dry ether, and the solid materials were separated by centrifugation. The pure peptides, obtained after a final purification step as described above, were characterized by a purity higher than 95\% (Table 2) by analytical RP-HPLC and MALDI-TOF analysis (Table 2).

Table 2. Analytical Data of CTX-I and Its Related Derivatives

compd name HPLC ${ }^{\mathrm{a}}(\%) \mathrm{MS}^{\mathrm{b}}$ calcdMS $^{\mathrm{b}}$ found

CTX-I $\quad 95 \quad 6692.2 \quad 6692.6$ 


\section{compd name HPLC ${ }^{\underline{a}}(\%) M^{\underline{b}}$ calcdMS $^{\underline{b}}$ found}

\begin{tabular}{|lrrr}
${\text { CTX }-\mathrm{I}_{1-39}}$ & 97 & 4326.4 & 4326.3 \\
& & & \\
${\text { CTX }-\mathrm{I}_{41-60}}$ & 98 & 2267.7 & 2267.6 \\
& & & \\
& & & \\
{$\left[\text { Lys }^{52}\right]_{\text {CTX }-I_{41-60} 98} 98$} & 2296.7 & 2298.9
\end{tabular}

a

Percentage of purity determined by HPLC using the eluent system: $A=\mathrm{H}_{2} \mathrm{O}(0.1 \%$ TFA $)$ and $\mathrm{B}=60 \% \mathrm{CH}_{3} \mathrm{CN} / 40 \% \mathrm{~A}$ with a gradient slope of $1 \% \mathrm{~B} / \mathrm{min}$, at a flow rate of $1 \mathrm{~mL} / \mathrm{min}$, on a Vydac analytical C18 column. Detection at $229 \mathrm{~nm}$.

b

Calculated $\mathrm{m} / \mathrm{z}$ of the monoisotope (obtained with ChemDraw Ultra 7.0.1) compared with the observed $[\mathrm{M}+\mathrm{H}]^{+}$monoisotopic mass.

\section{Cell Culture}

The rat pancreatic $\beta$-cell line (INS-1E) was a generous gift from Pr. Pierre Maechler (University of Geneva, Switzerland). Cells were maintained in RPMI-1640 culture medium supplemented with 10 mM HEPES, 10\% heat-inactivated fetal bovine serum (FBS), 2 mM glutamine, $1 \mathrm{mM}$ sodium pyruvate, $50 \mu \mathrm{M}$ 2-mercaptoethanol, and $100 \mathrm{U} / \mathrm{mL}$ of penicillin and streptomycin. Cells, grown as a monolayer at $37^{\circ} \mathrm{C}$ in a humidified atmosphere of $5 \% \mathrm{CO}_{2}$, were passaged by trypsinization once cells reached confluence.

\section{Intracellular Calcium Mobilization}

Intracellular free $\mathrm{Ca}^{2+}$ concentrations $\left(\left[\mathrm{Ca}^{2+}\right] \mathrm{i}\right)$ were measured using the fluorescent calcium indicator Fura-2-AM, as previously described.(18) The signaling pathway involved in CTX-Iinduced calcium release was investigated using various pharmacological inhibitors. Cells 
were cultured in $25 \mathrm{~cm}^{2}$ flask until $80 \%$ confluence was reached (up to 3 days). On the day of the experiment, the medium was removed and cells were pretreated with either diazoxide $(100 \mu \mathrm{M})$, a $\mathrm{K}_{\text {ATP }}$ channel opener, or nifedipine $(10 \mu \mathrm{M})$, a Ca ${ }^{2+}$ channel blocker, for $30 \mathrm{~min}$. Cells $\left(5 \times 10^{5} \mathrm{cells} / \mathrm{mL}\right)$, removed by scraping, were then incubated in Krebs-Ringer bicarbonate-HEPES buffer solution (135 mM NaCl, $3.6 \mathrm{mM} \mathrm{KCl,} 5 \mathrm{mM} \mathrm{NaHCO}$, $0.5 \mathrm{mM}$ $\mathrm{NaH}_{2} \mathrm{PO}_{4}, 0.5 \mathrm{mM} \mathrm{MgCl}_{2}, 1.5 \mathrm{mM} \mathrm{CaCl}_{2}, 10 \mathrm{mM}$ HEPES, $10 \mathrm{mM}$ glucose, $\mathrm{pH}$ 7.4) for another $30 \mathrm{~min}$ at $37^{\circ} \mathrm{C}$ with $4 \mu \mathrm{M}$ of Fura-2-AM and $2.5 \mathrm{mM}$ of probenecid. Cells were washed by centrifugation ( $780 \mathrm{~g} ; 10 \mathrm{~min}$ ) to remove the noninternalized fluorescent probe and the incubation was resumed for another 15 min. Finally, cells were washed twice with KrebsRinger bicarbonate-HEPES (KRBH) buffer and distributed in a 96-well plate (20000 cells/well). Measurements were immediately performed after peptide addition (CTX-I, CTX$\mathrm{I}_{41-60}$, and $\left[\right.$ Lys $\left.^{52}\right]$ CTX- $\left.\mathrm{I}_{41-60}\left(10^{-12}-10^{-5} \mathrm{M}\right)\right)$ by using a SpectraMax M5Multimode microplate reader with a dual excitation wavelength set at 340 and $380 \mathrm{~nm}$ and an emission at $495 \mathrm{~nm}$. $\left[\mathrm{Ca}^{2+}\right] \mathrm{i}$ was calculated using the Grynkiewicz equation, i.e., $\left[\mathrm{Ca}^{2+}\right]_{\mathrm{i}}=K_{\mathrm{d}} \times\left[\left(R-R_{\min }\right) /\left(R_{\max }-R\right)\right]$ $\times \mathrm{Sfb}$, where $K_{\mathrm{d}}$ for $\mathrm{Ca}^{2+}$ binding to Fura- 2 at $37^{\circ} \mathrm{C}=225 \mathrm{nM}, R=340 / 380$ ratio, $R_{\max }=$ $340 / 380$ ratio under $\mathrm{Ca}^{2+}$-saturating conditions, $R_{\min }=340 / 380$ ratio under $\mathrm{Ca}^{2+}$-free conditions, and $\mathrm{Sfb}=$ ratio of baseline fluorescence at $380 \mathrm{~nm}$ under $\mathrm{Ca}^{2+}$-free and -bound conditions.(50)

\section{Insulinotropic Activity}

The glucose-sensitive INS-1E cells were seeded at $2 \times 10^{5}$ cells/well in a 24 -well plate, 2 days before use.(18) On experimental day, cells were first pretreated for 30 min with the protein kinase A (PKA) specific inhibitor H89 $(40 \mu \mathrm{M})$ or the cell permeable adenylyl cyclase specific inhibitor 2'5'-dideoxyadenosine $(50 \mu \mathrm{M})$. After washing with glucose-free $\mathrm{KRBH}$ buffer supplemented with $0.1 \%(\mathrm{w} / \mathrm{v})$ bovine serum albumin (BSA), cells were incubated for 2 $h$ in a glucose-free $\mathrm{KRBH}$ buffer and then washed twice with the glucose-free $\mathrm{KRBH}$ buffer. Following a $30 \mathrm{~min}$ incubation at $37^{\circ} \mathrm{C}$ in a glucose-free $\mathrm{KRBH}$ buffer, cells were washed once with glucose-free $\mathrm{KRBH}$ buffer and then incubated at $37^{\circ} \mathrm{C}$ for $2 \mathrm{~h}$ with the appropriate peptide in the presence $(20 \mathrm{mM})$ or absence of glucose. Incubation was stopped by placing the plates on ice, and cell culture media were then collected to quantify secreted insulin using a commercially available RIA Kit (Millipore, St. Charles, MI, USA) following the manufacturer's protocol with rat insulin as the standard.

\section{Cell Viability}


INS-1E cells were seeded at a density of $2 \times 10^{4}$ cells/well in 96-well-plates and cultured at $37^{\circ} \mathrm{C}$ for $24 \mathrm{~h}$. Cells were then incubated in serum free media with increasing concentrations of peptides. Viability was assessed with a MTS kit (CellTiter 96 AQueous, Promega, Madison, WI, USA) and a microplate reader (MTX'C Revelation, Dynex Tech., VA, USA) to determine the optical density related to the conversion of MTS into purple-colored water-soluble formazan. Results were expressed as the percentage of control (nontreated cells). The presence of lactate dehydrogenase (LDH), released in the culture medium from dead cells, was determined using a commercial LDH kit (BioVision, Miltipas, CA, USA). Results were expressed as the percentage of the maximum LDH release following cell lysis.

\section{${ }^{86} \mathrm{Rb}+$ Efflux Assay}

INS-1E cells, plated at a density of $2 \times 10^{5}$ cells/well in 96-well plates, were incubated overnight at $37^{\circ} \mathrm{C}$ with $100 \mu \mathrm{L}$ of ${ }^{86} \mathrm{RbCl}$ in culture medium $(0.02 \mu \mathrm{Ci} / \mathrm{mL})$ Then, to each well, $100 \mu \mathrm{L}$ of low-potassium buffer $\left(135 \mathrm{mM} \mathrm{NaCl}, 4.6 \mathrm{mM} \mathrm{KCl}, 1 \mathrm{mM} \mathrm{CaCl}, 2 \mathrm{mM} \mathrm{MgCl}_{2}, 0.2 \%\right.$ bovine serum albumin, and $10 \mathrm{mM}$ HEPES, $\mathrm{pH}$ 7.4) with or without peptide was added, and incubation resumed for $30 \mathrm{~min}$ at $37^{\circ} \mathrm{C}$. At the end of this period, the medium was replaced with $200 \mu \mathrm{L}$ of high-potassium buffer $\left(140 \mathrm{mM} \mathrm{KCl}, 1 \mathrm{mM} \mathrm{CaCl}, 2 \mathrm{mM} \mathrm{MgCl}_{2}, 0.2 \%\right.$ bovine serum albumin, and $10 \mathrm{mM}$ HEPES, pH 7.4), with or without peptide, and ${ }^{86} \mathrm{Rb}^{+}$efflux was monitored for determined periods of time. To quantify the amount of ${ }^{86} \mathrm{Rb}^{+}$efflux, medium was removed from the wells, and $100 \mu \mathrm{L}$ was mixed with $100 \mu \mathrm{L}$ of Ecolite scintillation cocktail (Fisher Scientific, Nepean, ON, CAN). ${ }^{86} \mathrm{Rb}^{+}$content of the cells was determined by the addition of $100 \mu \mathrm{L}$ of scintillation cocktail into wells. Efflux was defined as the percentage of ${ }^{86} \mathrm{Rb}^{+}$in the low- or high-potassium buffer, normalized to the total radioactivity, including efflux solutions and cells. $I_{50}$ values represent the mean \pm SEM of three independent experiments performed in triplicate.

\section{Statistical Analysis}

Functional experiments were performed at least in triplicate and data, expressed as mean \pm SEM, were analyzed with the Prism software (GraphPad Software, San Diego, CA, USA). Statistical comparisons were performed by ANOVA followed by a Dunnett's multiple comparison test, and differences were considered significant when ${ }^{\star} P<0.05$, ${ }^{\star \star} P<0.01$, and ${ }^{* \star *} P<0.001$.

\section{\#Author Contributions}

T.T.N.N. and B.F. made an equal contribution to this study. 
The authors declare no competing financial interest.

Notes

Symbols and abbreviations are in accord with the recommendations of the IUPAC-IUB Joint Commission on Biochemical Nomenclature: Nomenclature and Symbolism for Amino Acids and Peptides. Biochem. J. 1984, 2 ((19)) 345-373, and of A Short Guide to Abbreviations and Their Use in Peptide Science. J. Peptide Sci. 2003, 9, 1-8. All optically active amino acids are of the L configuration.

Acknowledgment

This work was financially supported jointly by INRS and VAST (awarded to A.F.), NSERC Discovery grant RGPIN 402623-2011 (awarded to N.D.), and a FRQS Research Scholar Junior 1 Career Award (to N.D). We thank Pratul K. Agarwal and Arvind Ramanathan (Oak Ridge National Laboratories, Oak Ridge, Tennessee) for helpful discussions. We also thank Éric Déziel (INRS) for his generous support.

\section{Abbreviations Used}

CTX cardiotoxin

\section{CTX-I cardiotoxin-I}

CHT charybdotoxin

\section{Shk Stichodactyla toxin}

\section{Bgk Bunodosoma granulifera toxin}

\section{PDB Protein Data Bank}

KCa calcium $\left(\mathrm{Ca}^{2+}\right)$-activated potassium channels 
Kv voltage-gated potassium channels

IDR delayed rectifying currents

Kesa potassium crystallographically sited activation channel

$\mathbf{R b C l}$ rubidium chloride

$\operatorname{Cys}_{(\mathbf{A c m})}$-acetamidomethyl-L-cysteine 